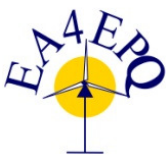

International Conference on Renewable Energies and Power Quality (ICREPQ'14)

Cordoba (Spain), $8^{\text {th }}$ to $10^{\text {th }}$ April, 2014

Renewable Energy and Pourer Quality. Fournal (RE\&PQJ)

ISSN 2172-038 X, No.12, April 2014

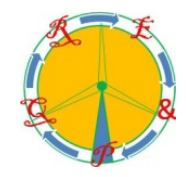

\title{
Steady State Analysis of a Medium/Low Voltage Distribution Grid Behavior with PV System Penetration
}

\author{
A. R. Piccini ${ }^{1}$, M. A. Tamashiro ${ }^{1}$, G. C. Guimarães $^{1}$, A. R. Rodrigues ${ }^{1}$ and C. S. Barbosa ${ }^{2}$ \\ ${ }^{1}$ Faculty of Electrical Engineering \\ Federal University of Uberlândia \\ Campus Santa Mônica - Uberlândia, Minas Gerais (Brazil)
}

Phone/Fax number:+5563 3239 4758, e-mail: anderson@ifto.edu.br, tamashiro@ifto.edu.br, andre.roger@ifmg.edu.br, gcaixeta@ufu.br

${ }^{2}$ Electrical company of Tocantins

CELTINS - Rede Energia

Department Planning System

Palmas, Tocantins (Brazil)

Phone/Fax number:+5563 32195103 e-mail: cristiano.barbosa@celtins.com.br

\begin{abstract}
This paper aims to present a preliminary study of the behavior of a distribution network with the penetration of grid-connected photovoltaic (PV) system. The work used measurements and data from an area of Palmas, the capital of Tocantins state, Brazil, which is attended by the power utility CELTINS. Three cases were analyzed here: (1) at a given daytime with the original distribution system, (2) at the same time with part of the distribution grid supplied by grid-connected PV systems, and (3) at a given nighttime. All the simulations were performed with PSAT software.
\end{abstract}

\section{Key words}

Distributed generation (DG), grid-connected photovoltaic (PV) system, PV penetration, PSAT, renewable energy.

\section{Introduction}

Distributed generation (DG), also called dispersed or embedded generation is a new approach in the electricity industry and, as the analysis of the relevant literature has shown, there is no generally accepted definition for the technical term [1]. In Brazil it is generally used to describe the generation of electricity close to consumer, regardless of capacity, technology and energy source [2]. DG takes advantage over centralized generation due to reductions of transmission and distribution losses and investments, thus improving electricity supply service [3]. DG allows greater diversification of technologies that make up the energy matrix, which leads to a more rational use of the primary sources available to produce electricity. The main DG technologies that use renewable source are: small hydroelectric plants, thermoelectric plants fueled by biomass, wind generators and photovoltaic systems [3]. Currently, large hydropower plants are responsible for $78.4 \%$ of all electricity produced in Brazil [4], but such plants are too far from major consuming centers. However, in the last decade, as has occurred in developed countries [5], there was a trend for increased distributed generation of electricity in the country due to the following causes: [6]:

- strong upward trend in electricity tariffs;

- restructuring of the Brazilian electric sector, new rules established by the Brazilian Electrical Energy Agency (ANEEL), legalization of the sale of electricity to the market for independent producers and self-producers;

- increasing availability of natural gas for generation, because of increase in supply, both domestic or foreign, the pipeline construction and the development of electricity distribution networks;

- awareness of environmental problems, promoting solutions to reduce the environmental impacts of the generation, among them, those that allow a better energy use from fossil or renewable fuels;

- technological improvements that make competitive the use of new processes and new sources of power generation in comparison to classical generation.

ANEEL approved in April 2012 rules intended to reduce barriers to the installation of small DG, including micro generation, up to $100 \mathrm{~kW}$ of power, and mini generation, from $100 \mathrm{~kW}$ to $1 \mathrm{MW}$. The objective was to facilitate the generation of electricity by consumers. The new rule creates the Energy Compensation System that allows consumers to install small generators and exchange energy with the local power utility. It is only valid for generators that use subsidized sources of energy such as hydro, solar, biomass, wind and qualified cogeneration. For this scheme, the generating unit installed in a residence (farm, etc.) will produce a certain amount of energy that, if not consumed, will be injected into the distribution system of the electricity company. Then, the power utility will use 
such energy as credit to discount in the consumption of subsequent months [4].

Thus, to enable consumers to become energy producers, one of the currently viable alternatives is the installation of grid-connected PV systems. However, there is not yet an exact idea of the impact of this kind of installation on the main grid. Based on this, this paper performs a evaluation of the behavior of certain part of the CELTINS's distribution network for the penetration of this type of generation. For this study, actual distribution system measurements are used and computer simulations are conducted using PSAT software.

\section{Characteristics of Distribution System}

For this work it was considered the block 1106 South, located in Palmas city, Tocantins, Brazil. It has approximately 700 consumers connected to the system, mostly residential ones (Fig. 1).

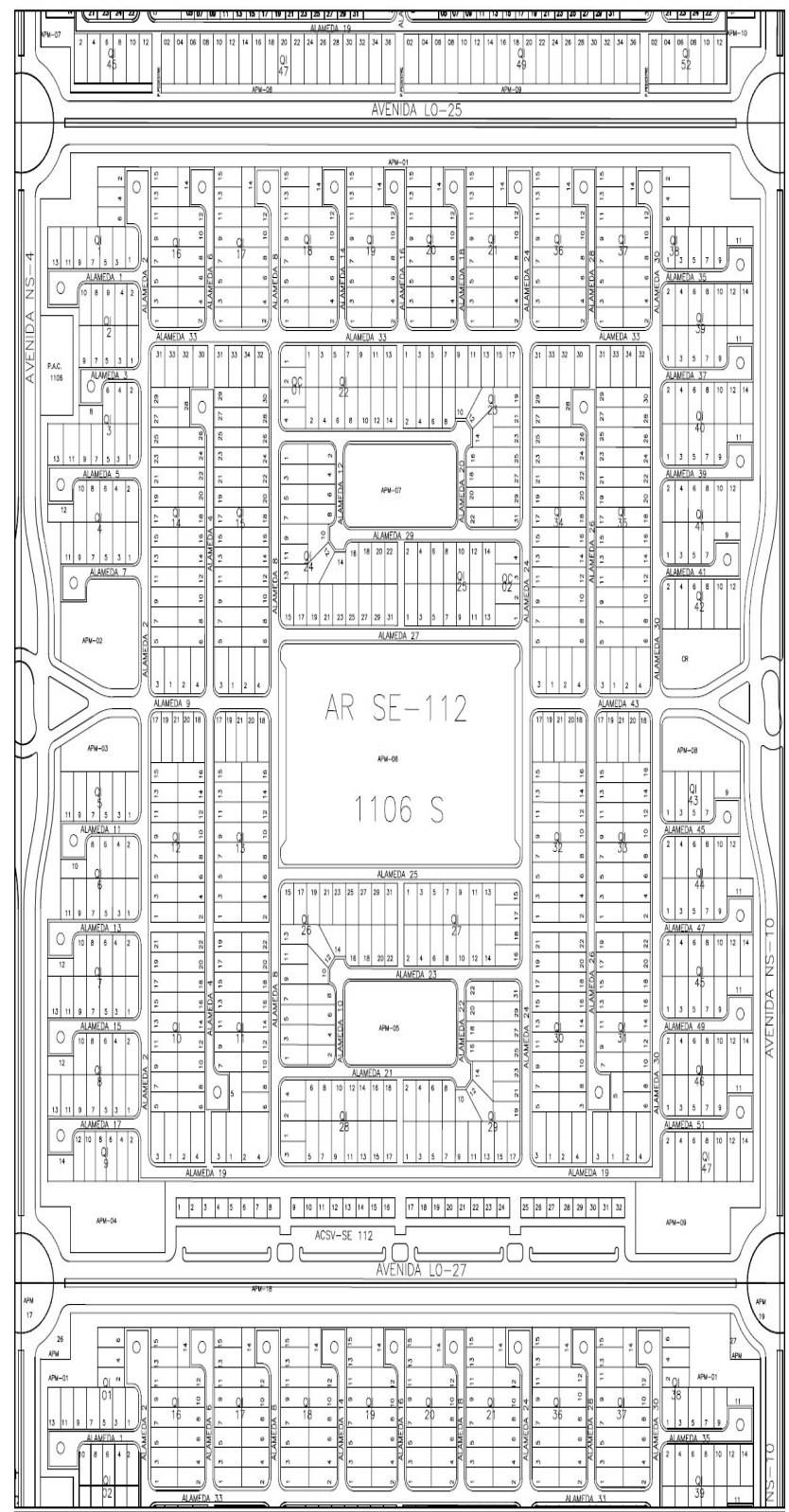

Fig. 1. Map of block 1106 South in the Palmas city [7].
The feeder from the substation number 2, called Palmas III, is responsible to provide electricity to all the CELTINS consumers installed in this block (Fig. 2).

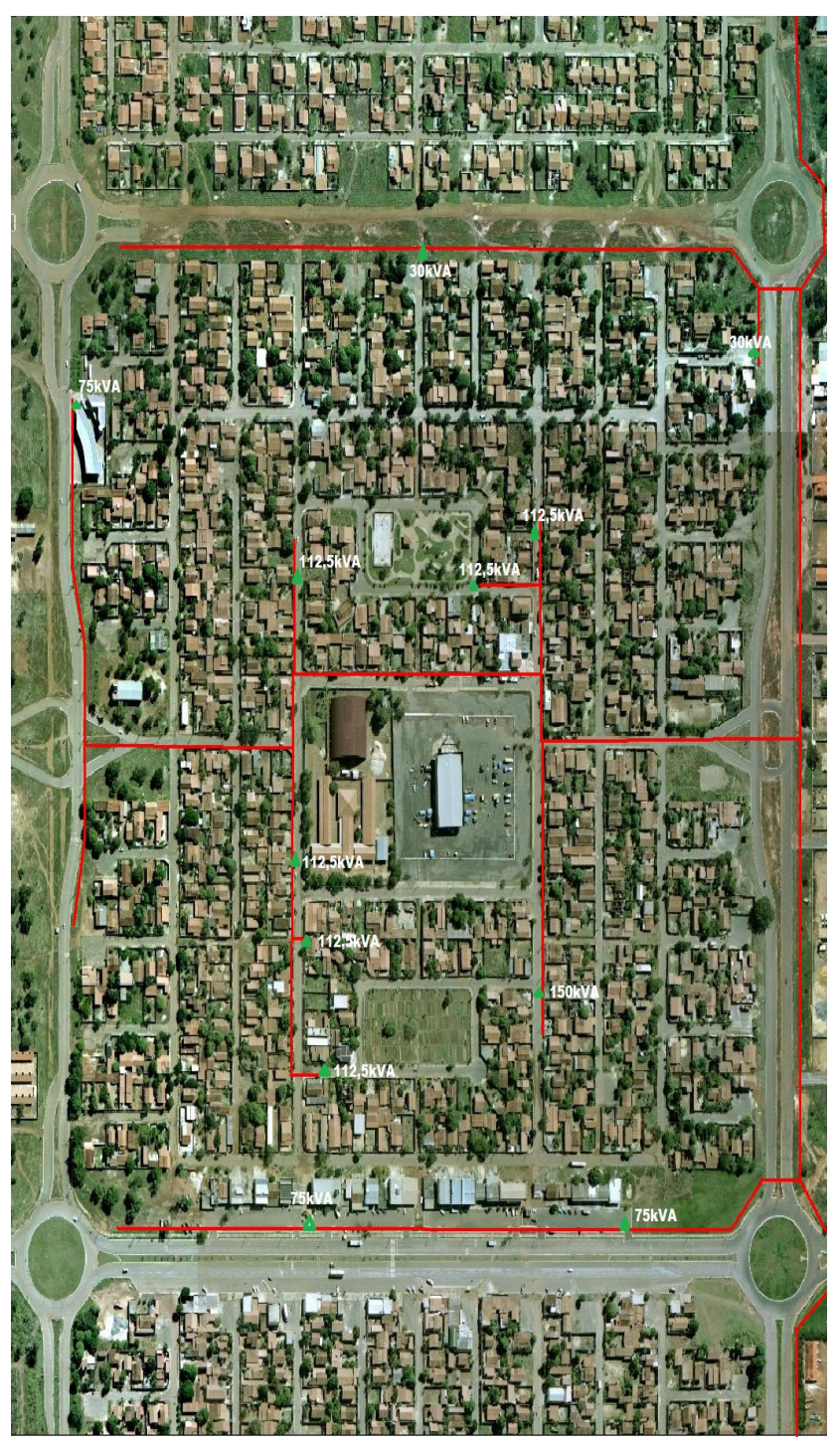

Fig. 2. Aerial photo [7], adapted by CELTINS, with the route network energy of block 1106 South.

This study also considered the following information extracted from software Eletricalc and the EU Viewer Elucid Solutions S/A (owned by CELTINS): transformer, load and branch data, input and output powers and voltages of the block distribution system, according to Tables I, II, III, IV and V.

Notes:

(a) The values given in the column "Max Power (kVA)" of Tables II and III are the maximum powers of the whole set of consumer units (CUs) connected to a given transformer at the time of study.

(b) Table $\mathrm{V}$ presents information (models and lengths of the cables) provided by CELTINS. With the aid of the available data in [8] the resistances and reactances could be calculated. 
TABLE I

Transformer Data (CELTINS)

\begin{tabular}{|c|c|c|c|c|c|}
\hline Bus & Bus & $\begin{array}{c}\text { Power } \\
(\mathbf{k V A})\end{array}$ & $\begin{array}{c}\text { Voltage } \\
\text { ratio (kV) }\end{array}$ & $\begin{array}{c}\text { Resistance } \\
(\mathbf{p u})\end{array}$ & $\begin{array}{c}\text { Reactance } \\
(\mathbf{p u})\end{array}$ \\
\hline 4 & 5 & 75 & $13.8 / 0.38$ & 0.0160 & 0.0311 \\
\hline 6 & 7 & 30 & $13.8 / 0.38$ & 0.0190 & 0.0294 \\
\hline 9 & 10 & 112.5 & $13.8 / 0.38$ & 0.0147 & 0.0318 \\
\hline 11 & 12 & 112.5 & $13.8 / 0.38$ & 0.0147 & 0.0318 \\
\hline 13 & 14 & 112.5 & $13.8 / 0.38$ & 0.0147 & 0.0318 \\
\hline 15 & 16 & 112.5 & $13.8 / 0.38$ & 0.0147 & 0.0318 \\
\hline 19 & 20 & 112.5 & $13.8 / 0.38$ & 0.0147 & 0.0318 \\
\hline 21 & 22 & 112.5 & $13.8 / 0.38$ & 0.0147 & 0.0318 \\
\hline 24 & 25 & 30 & $13.8 / 0.38$ & 0.0190 & 0.0294 \\
\hline 28 & 29 & 150 & $13.8 / 0.38$ & 0.0137 & 0.0322 \\
\hline 31 & 32 & 75 & $13.8 / 0.38$ & 0.0160 & 0.0311 \\
\hline 33 & 34 & 75 & $13.8 / 0.38$ & 0.0160 & 0.0311 \\
\hline 38 & 39 & 112.5 & $13.8 / 0.38$ & 0.0147 & 0.0318 \\
\hline
\end{tabular}

TABLE II

Loads connected to transformers at 2:45 pm in October 3, 2012

\begin{tabular}{|c|c|c|c|}
\hline Bus & $\begin{array}{c}\text { Voltage } \\
(\mathbf{k V})\end{array}$ & $\begin{array}{c}\text { Number of consumers } \\
\text { connected to the bus }(*)\end{array}$ & $\begin{array}{c}\text { Max Power } \\
(\mathbf{k V A})\end{array}$ \\
\hline 5 & 0.38 & $13 \mathrm{R}, \mathrm{C}$ & 8.52 \\
\hline 10 & 0.38 & $280 \mathrm{R}$ & 15.75 \\
\hline 12 & 0.38 & $1 \mathrm{P}$ & 50.23 \\
\hline 14 & 0.38 & $251 \mathrm{R}$ & 15.25 \\
\hline 16 & 0.38 & $122 \mathrm{R}$ & 18.55 \\
\hline 20 & 0.38 & $171 \mathrm{R}$ & 11.28 \\
\hline 22 & 0.38 & $309 \mathrm{R}$ & 15.43 \\
\hline 29 & 0.38 & $265 \mathrm{R}$ & 19.61 \\
\hline 32 & 0.38 & $4 \mathrm{C}$ & 15.17 \\
\hline 34 & 0.38 & $11 \mathrm{C}$ & 24.98 \\
\hline 39 & 0.38 & $1 \mathrm{I}$ & 8.34 \\
\hline
\end{tabular}

(*) R, C, P, I stand for Residential, Commercial, Public, Industrial CU, respectively.

TABLE III

Loads connected to transformers at 9:45 pm in October 3, 2012

\begin{tabular}{|c|c|c|c|}
\hline Bus & $\begin{array}{c}\text { Voltage } \\
(\mathbf{k V})\end{array}$ & $\begin{array}{c}\text { Number of consumers } \\
\text { connected to the bus }\left(^{*}\right)\end{array}$ & $\begin{array}{c}\text { Max. Power } \\
(\mathbf{k V A})\end{array}$ \\
\hline 5 & 0.38 & $13 \mathrm{R}, \mathrm{C}$ & 55.53 \\
\hline 10 & 0.38 & $280 \mathrm{R}$ & 72.00 \\
\hline 12 & 0.38 & $1 \mathrm{P}$ & 61.55 \\
\hline 14 & 0.38 & $251 \mathrm{R}$ & 81.29 \\
\hline 16 & 0.38 & $122 \mathrm{R}$ & 71.86 \\
\hline 20 & 0.38 & $171 \mathrm{R}$ & 55.48 \\
\hline 22 & 0.38 & $309 \mathrm{R}$ & 85.90 \\
\hline 29 & 0.38 & $265 \mathrm{R}$ & 85.67 \\
\hline 32 & 0.38 & $4 \mathrm{C}$ & 9.17 \\
\hline 34 & 0.38 & $11 \mathrm{C}$ & 14.99 \\
\hline 39 & 0.38 & $1 \mathrm{I}$ & 4.34 \\
\hline
\end{tabular}

(*) R, C, P, I stand for Residential, Commercial, Public, Industrial CU, respectively.

TABLE IV

Active and reactive powers, and voltages (CELTINS)

\begin{tabular}{|l|c|c|}
\hline \multicolumn{3}{|c|}{ Bus 37 - system input busbar } \\
\hline & $\mathbf{2 : 4 5} \mathbf{~ p m}$ & $\mathbf{9 : 4 5} \mathbf{~ p m}$ \\
\hline $\mathbf{P}(\mathbf{k W})$ & 2683.95 & 2311.71 \\
\hline $\mathbf{Q}(\mathbf{k V A r})$ & 1598.16 & 1412.61 \\
\hline $\mathbf{V}(\mathbf{k V})$ & 13.62 & 14.08 \\
\hline \multicolumn{2}{|c|}{ Bus 1 - system output busbar (for other blocks) } \\
\hline $\mathbf{P}(\mathbf{k W})$ & 2292.26 & 1701.48 \\
\hline $\mathbf{Q}(\mathbf{k V A r})$ & 1374.58 & 966.26 \\
\hline $\mathbf{V}(\mathbf{k V})$ & 13.58 & 14.03 \\
\hline
\end{tabular}

TABLE V

Branch Data (CELTINS)

\begin{tabular}{|c|c|c|c|c|c|}
\hline $\begin{array}{c}\text { Cable } \\
\text { model } \\
\text { AWG/ } \\
\text { MCM }\end{array}$ & $\begin{array}{c}\text { From } \\
\text { Bus }\end{array}$ & $\begin{array}{c}\text { To } \\
\text { Bus }\end{array}$ & Length (km) & $\begin{array}{c}\text { Resistance } \\
\text { (pu) }\end{array}$ & $\begin{array}{c}\text { Reactance } \\
\text { (pu) }\end{array}$ \\
\hline 2 & 2 & 3 & 0.201 & 0.010166 & 0.003610 \\
\hline $2 / 0$ & 2 & 4 & 0.237 & 0.005962 & 0.003926 \\
\hline $2 / 0$ & 6 & 23 & 0.319 & 0.008025 & 0.005285 \\
\hline 2 & 23 & 24 & 0.075 & 0.003793 & 0.001347 \\
\hline 2 & 3 & 8 & 0.046 & 0.002327 & 0.000826 \\
\hline 2 & 8 & 9 & 0.063 & 0.003186 & 0.001131 \\
\hline 2 & 17 & 8 & 0.237 & 0.011987 & 0.004256 \\
\hline 2 & 3 & 11 & 0.078 & 0.003945 & 0.001401 \\
\hline 2 & 11 & 13 & 0.064 & 0.003237 & 0.001149 \\
\hline 2 & 13 & 15 & 0.16 & 0.008092 & 0.002873 \\
\hline $2 / 0$ & 30 & 31 & 0.158 & 0.003975 & 0.002618 \\
\hline $2 / 0$ & 31 & 33 & 0.285 & 0.007170 & 0.004722 \\
\hline $2 / 0$ & 37 & 30 & 0.05 & 0.001258 & 0.000828 \\
\hline 2 & 37 & 38 & 0.044 & 0.002225 & 0.000790 \\
\hline $2 / 0$ & 30 & 26 & 0.175 & 0.004403 & 0.002899 \\
\hline 2 & 26 & 27 & 0.246 & 0.012442 & 0.004418 \\
\hline 2 & 27 & 28 & 0.134 & 0.006777 & 0.002406 \\
\hline 2 & 27 & 17 & 0.096 & 0.004855 & 0.001724 \\
\hline 2 & 17 & 18 & 0.085 & 0.004299 & 0.001526 \\
\hline 2 & 18 & 19 & 0.122 & 0.006170 & 0.002191 \\
\hline 2 & 18 & 21 & 0.055 & 0.002782 & 0.000988 \\
\hline $2 / 0$ & 26 & 1 & 0.175 & 0.004403 & 0.002899 \\
\hline $2 / 0$ & 23 & 1 & 0.05 & 0.001258 & 0.000828 \\
\hline & & & & & \\
\hline
\end{tabular}

The power values of PV Panels were defined by the authors in Table VI in order to perform the simulations of Case 2 shown in Section IV (Case Studies).

TABLE VI

PV generation (defined by the authors)

\begin{tabular}{|c|c|}
\hline Bus & $\begin{array}{c}\text { Power of PV Panels } \\
(\mathbf{k W})\end{array}$ \\
\hline 5 & 10.30 \\
\hline 7 & 0 \\
\hline 10 & 18.20 \\
\hline 12 & 15.00 \\
\hline 14 & 16.90 \\
\hline 16 & 7.80 \\
\hline 20 & 11.70 \\
\hline 22 & 19.50 \\
\hline 25 & 0 \\
\hline 29 & 16.90 \\
\hline 32 & 4.00 \\
\hline 34 & 11.00 \\
\hline 39 & 0 \\
\hline
\end{tabular}

\section{Modeling of Distribution System}

Based on system data, shown in Tables I, II, III, IV and V, it was performed a complete modeling of the medium/low voltage distribution system using the software PSAT (see Fig. 3).

The simulations were configured with the parameters shown in Tables I, II, IV, V and VI for the day 03/10/12 at 2:45 pm, excluding and including DG, and with load data from Table III (at 9:45 pm) without the presence of DG. 


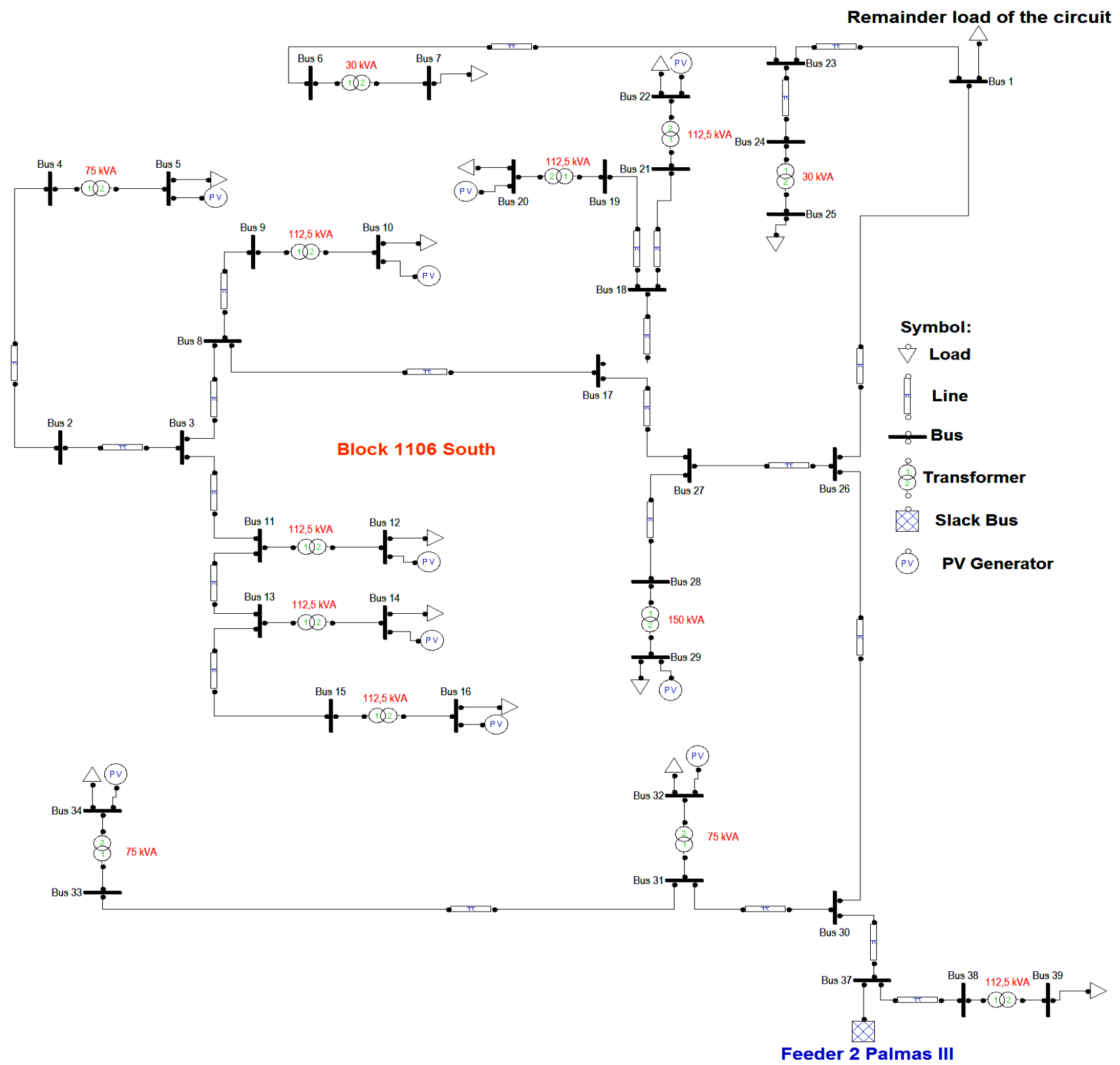

Fig. 3. Network model created with PSAT

\section{Case Studies}

The case studies were performed with PSAT software using the information provided by the electrical company for day 03/10/2012 at 2:45 pm and 9:45 pm.

\section{A. Case 1}

The above date was chosen for this work because it was when there was the register of the highest consumption of daylight energy during that year (without the PV system) according to the power utility. For this first study, the aim was to verify if load flow results (voltages and powers) were in agreement with the information received from CELTINS and similar to the real system at time 2:45 pm. A file with these data was generated by PSAT using the function Power Flow.
In Table II, the last column described as "Max Power (kVA)" presented the total power of the consumer units at a given time $(2: 45 \mathrm{pm})$.

\section{B. Case 2}

A model based on assumptions and characteristics of the work presented by Albuquerque in 2012 [9] was used to analyze the operation of PV systems. Taking into account the same electrical configuration of Case 1, PV systems were then inserted according to column "Power of PV Panels (kW)", as shown in Table VI, adopting the following criteria:

(a) for residential (R) CUs: $5 \%$ of all CU connected to the transformer with PV panel power equal to $1.3 \mathrm{~kW}$, occupying approximately $12 \mathrm{~m}^{2}$ of each residence roof. These data were collected from a tool called Solar 
Simulator, developed by a partnership between the Brazilian company called Institute Ideal and a German Cooperation formed by Deutsche Gesellschaft für Internationale Zusammenarbeit (GIZ) GmbH and Kreditanstalt für Wiederaufbau (KfW) [10][11].

(b) for commercial (C) CUs: values which are compatible with the needs of the installations.

(c) for public (P) CUs:

Then, with the above assumptions, the PSAT Power Flow was executed and a new data file was generated.

\section{Case 3}

This case considered the greatest consumption during the nighttime which occurred at 9:45 pm. Thus, a new simulation was performed now using the data in Table III without PV systems.

\section{Analysis of Results}

Table VII shows the active, reactive and apparent powers, as well as the power factor provided by the electrical company through the feeder number 2 for all cases. Comparing case 1 with case 2 , it can be observed reductions in the powers and considerably improvements in power factors (PF) due the presence of PV systems. This reinforces the need for the PV system to also perform the compensation of reactive. Albuquerque showed and proved the viability this compensation [12].

Notice that the power consumption (without PV systems) during the day or nighttime are quite the same because the distribution system studied has a large presence of air conditioners. This fact is normally observed in that tropical region which presents high temperatures along the whole year.

TABLE VII

Power provided by feeder number 2 of Palmas III

\begin{tabular}{|c|c|c|c|}
\hline $\begin{array}{c}\text { Feeder no. 2 } \\
\text { Palmas III }\end{array}$ & $\begin{array}{c}\text { Daytime } \\
\text { without PV } \\
\text { system } \\
\text { (Case 1) }\end{array}$ & $\begin{array}{c}\text { Daytime } \\
\text { with PV } \\
\text { system } \\
\text { (Case 2) }\end{array}$ & $\begin{array}{c}\text { Nighttime } \\
\text { (Case 3) }\end{array}$ \\
\hline P [MW] & 2.4896 & 2.3605 & 2.2688 \\
\hline Q [MVar] & 1.4536 & 0.9040 & 1.2014 \\
\hline S [MVA] & 2.8829 & 2.5277 & 2.5673 \\
\hline FP & 0.8636 & 0.9339 & 0.8837 \\
\hline
\end{tabular}

Fig. 4 and 5 show, respectively, that the active and reactive power flows in several branches of the distribution system decrease because of PV systems connected to the grid.

It can be seen from Fig. 6 that all transformer secondary windings, where PV systems are connected, the voltages have stabilized at $380 \mathrm{~V}$ ensuring a constant voltage level to supply the loads. This shows the improvement of power quality as a result of PV penetration.

Values of primary voltages also result in a small increase due to these conditions. This shows the improvement in the voltage regulation in transformer of the electrical system studied.

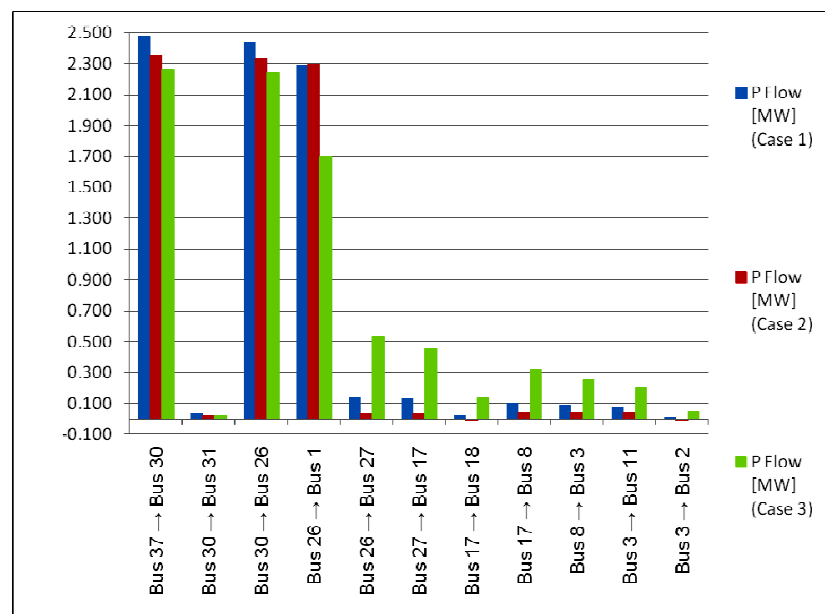

Fig. 4. Graph of active power flows of the system analyzed.

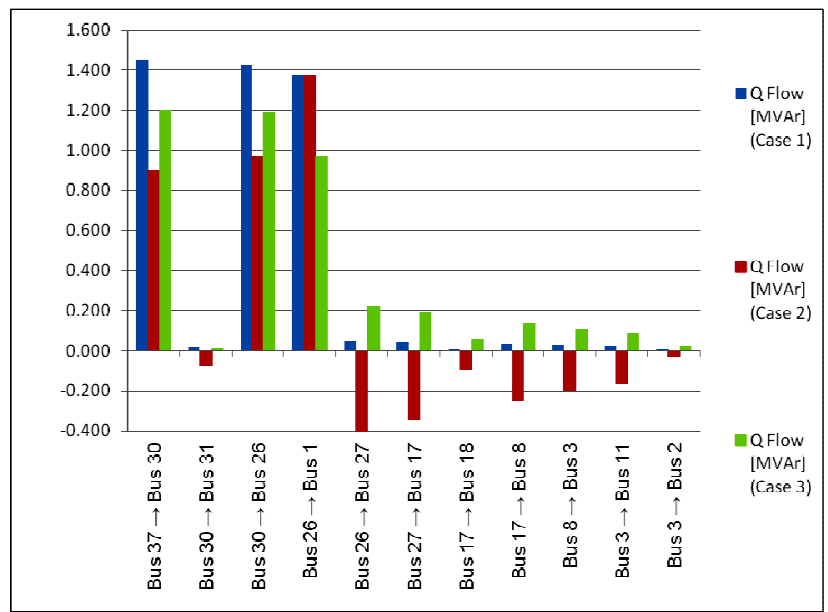

Fig. 5. Graph of reactive power flows of the system analyzed.

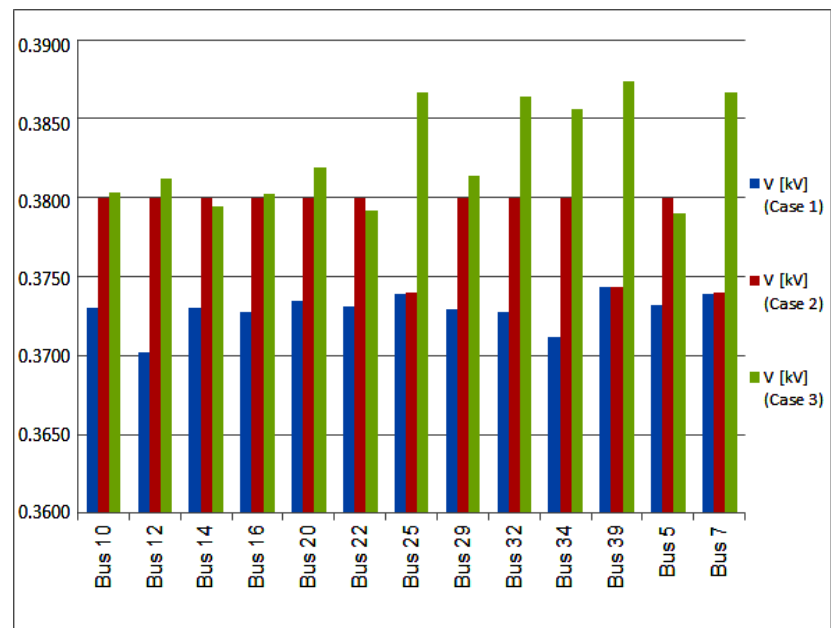

Fig. 6. Graph of bus voltages of transformer secondaries.

\section{Conclusion}

This study analyzed the results of simulations of a real power system, installed in Palmas-TO, at block 1106 South. The simulation considered the insertion of PV systems to a number of customers connected to some transformers

It was possible to observe a reduction in the energy delivered by the electrical company and an increase in 
power factor of the system with the penetration of PV systems in this block. It is important to note that the block has power consumptions during the whole day ( 24 hours), however, the analysis considered only highest consumption moments.

It is noteworthy that, from the moment that the PV systems become more popular, there may be a greater number of homes, businesses and public facilities with this kind of DG system, allowing the use of this source of clean and renewable energy which is abundant not only in this city but also throughout Brazil.

Thus, PV systems allow users to achieve a significant reduction in power consumption and can compensate their bills by the power equivalent produced, respecting the normative resolution $\mathrm{N}^{\circ} 482$ of ANEEL [4]. The effect is beneficial for the power distribution network due to the decrease in transformer and cable loadings, with a consequent reduction of electrical losses and power factor increase [13]. And it may be a new source of income and employment for the population [14].

In order to sensibly improve the analysis of the results, new investigations will be performed for the PV system penetration, covering a whole day (twenty four hours period).

\section{Acknowledgement}

The authors acknowledge the funding support received from the Brazilian research agencies: FAPEMIG, CAPES and $\mathrm{CNPq}$, and also the technical support from power utility CELTINS.

\section{References}

[1] T. Ackermann, G. Andersson, L. Söder, Distributed generation: a definition, Elsevier, Electric Power Systems Research, vol. 57, 2001, pp. 195-204.

[2] INEE. Sobre GD e Cogeração. Instituto Nacional de Eficiência Energética - INEE. Available at: $<$ http://www.inee.org.br/>. Accessed May 17, 2013.
[3] LORA, E. E. S.; ADDAD, J. "Geração Distribuída Aspectos Tecnológicos, Ambientais e Institucionais". Rio de Janeiro: Editora Interciência, 2006.

[4] ANEEL. Procedimentos de Distribuição de Energia Elétrica no Sistema Elétrico Nacional - PRODIST Modulo 3., 2012.

[5] L. Gan, G. S. Eskelanda, and H. H. Kolshus, "Green electricity market development: Lessons from Europe and the US", Energy Policy, Vol. 35, No. 1, pp. 144-155, Elsevier Ltd., 2007.

[6] ANEEL. Informações Gerais $1^{\circ}$ Trimestre de 2013. Agencia Nacional de Energia Elétrica - ANEEL. Disponivel em:

$<$ http://www.aneel.gov.br/arquivos/PDF/Z_IG_Mar_2013.p df>. Acesso em: 17 maio 2013.

[7] Secretaria de Desenvolvimento Urbano e Habitação Prefeitura Municipal de Palmas-To. Disponível em: $<$ http://srvsefin.palmas.to.gov.br/portalprefeitura/servicos/s eduh/>. Acesso em: 01 outubro 2013.

[8] Tabela de Cabos e Fios. Disponivel em: $<$ http://www.dicelrs.com.br/index.php?pagina=produto\&id $=42 \&$ chamada $=$ TABELAS $>$. Acesso em: 06 de setembro 2013.

[9] ALBUQUERQUE, F. L. et al. "Análise da Curva de Carga em Prédios Públicos com Sistemas Fotovoltaicos Conectados à Rede Dotados de Compensação de Potência Reativa". IV Simpósio Brasileiro de Sistemas Elétricos (SBSE 2012). Goiânia, Goiás: [s.n.]. 2012.

[10] Instituto Ideal lança Simulador Solar. Disponível em: $<$ http://www.jornaldaenergia.com.br/ler_noticia.php?id_not icia $=12973 \&$ id_tipo $=3 \&$ id_secao $=8 \&$ id_pai $=2 \&$ titulo_info $=$ Instituto $\% 20 I d e a 1 \% 201 a n \% 26$ ccedil $\% 3 \mathrm{Ba} \% 20$ Simulador $\% 20$ Solar>. Acesso em: 16 abril 2013

[11] Simulador Solar. Disponível em: $<$ http://www.americadosol.org/simulador/>. Acesso em: 16 abril 2013.

[12] ALBUQUERQUE, F. L.; Moraes, Adélio J.; Guimarães, Geraldo C.; Sanhueza, Sérgio M.R.; Vaz, Alexandre R. .'Photovoltaic solar system connected to the electric power grid operating as active power generator and reactive power compensator". Solar Energy, v. 84, p. 1310-1317, 2010.

[13] VILlALVA, M. G.; GAZOLI, J. R. "Energia Solar Fotovoltaica”. 1. ed. São Paulo: Editora Érica Ltda, 2012.

[14] Microgeração solar chega a mil residências na Bahia. Disponível

em: $<$ http://www.jornaldaenergia.com.br/ler_noticia.php?id_not icia $=12977 \&$ id_tipo $=3 \& i d \_s e c a o=8>$. Acesso em: 16 abril 2013. 